\title{
ANALISIS KESALAHAN DALAM MENYELESAIKAN SOAL-SOAL BENTUK PERSAMAAN DAN PERTIDAKSAMAAN LINEAR SATU VARIABEL PADA SISWA KELAS VII SMP NEGERI 2 KENDARI
}

\author{
Ays Karlina ${ }^{()}$, La Masi ${ }^{2)}$, Kodirun ${ }^{3)}$ \\ ${ }^{1)}$ Alumni Jurusan Pendidikan Matematika, ${ }^{2,3)}$ Dosen Jurusan Pendidikan \\ Matematika FKIP Universitas Halu Oleo: email: ays.karlina@yahoo.co.id; \\ lamasimbahido1966@yahoo.co.id; kodirunzuhry@gmail.com
}

\begin{abstract}
Abstrak
Penelitian ini bertujuan untuk mengetahui kesalahan yang dilakukan siswa dalam menyelesikan soal persamaan dan pertidaksamaan linear satu variabel dan Untuk mengetahui faktor penyebab kesalahan siswa dalam menyelesikan soal persamaan dan pertidaksamaan linear satu variabel. Penelitian ini adalah jenis penelitian kualitatif dan metode yang digunakan adalah metode deskriptif kualitatif. Penelitian ini dilakukan di SMP Negeri 2 Kendari tahun ajaran 2017/2018 pada kelas VIIA. Hasil yang diperoleh dalam penelitian ini: (1) Jenis kesalahan yang dilakukan siswa meliputi kesalahan fakta, konsep, prinsip, dan operasi, dan (2) Faktor penyebab terjadinya kesalahan adalah siswa kurang teliti dalam membaca soal, siswa tidak paham maksud dari soal yang diberikan sehingga tidak tahu bagaimana cara menjawab soal tersebut, siswa keliru dalam menuliskan satuan, siswa masih kurang paham bagaimana cara menyamakan kedua ruas, siswa tidak tahu bagaimana cara mengubah soal menjadi model matematika pada soal cerita.
\end{abstract}

Kata Kunci: analisis kesalahan siswa, persamaan linear, pertidaksamaan linear

\section{ANALYSIS OF ERRORS IN SOLVING PROBLEMS OF EQUATIONS AND LINEAR INEQUALITIES OF ONE VARIABLE IN THE SEVENTH GRADE STUDENTS OF SMP NEGERI 2 KENDARI}

\begin{abstract}
This study aims to determine the errors that students do in solving the problem of equations and linear inequality one variable and To determine the factors causing student error in solving the problem of equations and linear inequality one variable. This research is a type of qualitative research, the method used is descriptive qualitative method. This research was conducted in SMP Negeri 2 Kendari academic year 2017/2018 at class VIIA. The results obtained in this research: (1) The type of mistakes made by students include facts errors, concepts, principles, and operations, and (2) The factors causing the error are the students are less thorough in reading questions, students do not understand the purpose of the given problem so do not know how to answer the problem, students mistaken in writing the unit, the students still do not understand how to equate the two segments, the students do not know how to turn the matter into a mathematical model on the story.
\end{abstract}

Keywords: Analysis Of Students Error.linear equality, linear inequality 


\section{Pendahuluan}

Pendidikan merupakan upaya pemerintah untuk meningkatkan kualitas sumber daya manusia agar lebih baik lagi dari sebelumnya. Undang-Undang Nomor 20 Tahun 2003 tentang Sistem Pendidikan Nasional, pasal 1 ayat 1 menyatakan bahwa pendidikan adalah usaha sadar dan terencana untuk mewujudkan suasana belajar dan proses pembelajaran agar siswa secara aktif mengembangkan potensi dirinya untuk memiliki kekuatan spiritualkeagamaan, pengendalian diri, kepribadian, kecerdasan, akhlak mulia, serta keterampilan yang diperlukan dirinya, masyarakat, bangsa, dan Negara.

Matematika merupakan mata pelajaran yang sudah diajarkan sejak pendidikan dasar sampai pendidikan lanjut. Namun tidak sedikit siswa yang mengalami kesulitan dalam pembelajaran matematika. Terdapat materi yang dengan mudah dipahami oleh siswa, tetapi juga ada materi yang tidak dengan mudah untuk dipahami. Ada juga materi yang mudah tetapi juga tidak dengan mudah dipahami karena kemungkinan terdapat beberapa faktor yang menghambat pemahaman pada siswa, baik faktor internal maupun eksternal.

Proses pembelajaran ada peran guru, bahan belajar, dan lingkungan kondusif yang sengaja diciptakan. Selain itu, proses pembelajaran juga melibatkan proses mental siswa secara maksimal, bukan hanya menuntut siswa sekedar mendengar dan mencatat, akan tetapi menghendaki aktifitas siswa dalam proses berpikir. Proses pembelajaran merupakan suatu orchestra pembelajaran dan suatu perpaduan seni pembelajaran dan ilmu pembelajaran. Kekurangtepatan dalam melaksanakan proses pendidikan akan membawa dampak terganggunya pencapaian tujuan yang sesungguhnya (Muri Yusuf, 2015: 151).

Tujuan pembelajaran matematika menurut BSNP (2006: 148), yaitu agar siswa memiliki kemampuan: (1) Memahami konsep matematika, menjelaskan keterkaitan antar konsep, dan mengaplikasikan konsep atau algoritma secara luwes, akurat, efisien, dan tepat dalam pemecahan masalah. (2) Mengkomunikasikan gagasan dengan simbol, tabel, diagram atau media lain untuk memperjelas masalah. (3) Menggunakan penalaran pada pola dan sifat, melakukan manipulasi matematika dalam membuat generalisasi, menyusun bukti, atau menjelaskan gagasan dan pernyataan matematika. (4) Memecahkan masalah yang meliputi kemampuan memahami masalah, merancang model matematika, menyelesaikan model dan menafsirkan solusi yang diperoleh. (5) Memiliki sikap menghargai kegunaan matematika dalam kehidupan, yaitu memiliki rasa ingin tahu, perhatian, dan minat dalam mempelajari matematika, serta sikap ulet dan percaya diri dalam pemecahan masalah.

Adapun pencapaian dalam tujuan pendidikan dan pembelajaran matematika dapat dinilai dari keberhasilan siswa dalam memahami matematika dan memanfaatkannya untuk menyelesaikan persoalan matematika yang disajikan dalam tes hasil belajar. Namun, pada kenyataan di sekolah masih sering ditemukan beberapa siswa yang memiliki nilai hasil belajar di bawah rata-rata. Hal ini dikarenakan bahwa adanya siswa yang mengalami kesulitan dalam menyelesaikan masalah matematika. Kesulitan inilah yang menyebabkan beberapa siswa mengalami kesalahan dalam menyelesaikan soal tertentu. Menurut Sukirman (Meylan, 2012: 3) kesalahan merupakan bentuk penyimpangan dari hal yang benar yang sifatnya sistematis dan konsisten pada materi tertentu. Kesalahan yang sistematis dan konsisten disebabkan oleh kompetensi siswa yang mengakibatkan rendahnya penguasaan materi pembelajaran.

Salah satu materi yang sulit dipahami dalam pembelajaran matematika SMP kelas VII adalah pada pokok bahasan persamaan dan pertidaksamaan linear satu variabel, karena para siswa dituntut untuk menguasai konsepnya agar nanti bisa memahami dengan benar dalam mengenal sistem persamaan dan pertidaksamaan linear satu variabel. Persamaan dan pertidaksamaan linear satu variabel merupakan salah satu bagian matematika terapan yang banyak manfaatnya di berbagai bidang antara lain, bidang pembangunan, pengukuran, perbandingan, dan lain-lain. Penguasaan siswa pada materi persamaan dan pertidaksamaan linear satu variabel antara lain ditunjukkan dengan kemampuan siswa menyelesaikan soal dengan benar. Akan tetapi, dari hasil pengalaman peneliti maupun guru di kelas dan hasil pekerjaan siswa dalam tes dijumpai berbagai macam kesalahan dalam penyelesaian 
soal, salah satunya yaitu siswa sulit dalam membuat persamaan yang berbentuk soal cerita. Selain itu juga siswa masih kurang mengerti mengenai penggunaan bilangan dalam menyamakan kedua ruas. Hal ini kemungkinan siswa kurang memahami konsep dan beberapa materi sebelumnya terkait dengan materi persamaan dan pertidaksamaan linear satu variabel. Selain kesalahan-kesalahan tersebut, tidak tertutup kemungkinan masih terdapat kesalahan-kesalahan lainnya yang dilakukan oleh siswa. Untuk mengatasi hal tersebut maka diperlukan perhatian dari setiap guru sehingga mampu menciptakan suasana dalam proses pembelajaran yang dapat mendorong siswa belajar menjadi lebih aktif.

Kesalahan mempelajari suatu konsep terdahulu dalam pembelajaran matematika akan berpengaruh terhadap pemahaman konsep berikutnya karena matematika merupakan pelajaran yang terstruktur. Hudojo (2005: 3) menyatakan bahwa matematika berkenaan dengan ide-ide atau konsep-konsep abstrak yang tersusun secara hirarkis dan penalarannya deduktif. Oleh karenanya, dalam proses pembelajaran matematika tidak semua siswa selalu berhasil mencapai tujuan pembelajaran. Jika ada saja siswa yang tidak dapat belajar, ini berarti siswa mengalami kesulitan yang berakibat pada terjadinya kesalahan dalam menyelesaikan soal-soal matematika.

Peneliti memilih materi persamaan dan petidaksamaan linear satu variabel selain mengingat pengalaman belajar yang lalu yang masih jauh dari jawaban sempurna, peneliti juga telah mewawancarai salah satu guru matematika di SMP Negeri 2 Kendari bahwa pencapaian siswa dalam mempelajari pokok bahasan persamaan dan pertidaksamaan linear satu variabel masih sangat rendah. Masih banyak kesalahan-kesalahan yang dilakukan siswa dalam menyelesaikan soal. Hal ini dikarenakan adanya faktor-faktor tertentu yang menyebabkan terjadinya kesalahan. Untuk itu, kesalahankesalahan yang dilakukan siswa tersebut harus segera diatasi untuk menghindari kesalahan yang akan dilakukan setelahnya, karena siswa akan tetap melakukan kesalahan jika kesalahan sebelumnya tidak diperbaiki. Dengan melakukan analisis kesalahan dalam menyelesaikan soal, maka guru dapat mengetahui jenis kesalahan apa yang dilakukan siswa dan penyebab terjadinya kesalahan yang dilakukan siswa dalam menyelesaikan soal. Hal ini dimaksudkan agar siswa tidak mengulangi kesalahannya

Aunnurrahman (2012: 33), belajar merupakan kegiatan penting setiap orang, termasuk di dalamnya belajar bagaimana seharusnya belajar. Sebuah survey memperlihatkan bahwa $82 \%$ anak-anak yang masuk sekolah pada usia 5 atau 6 tahun memiliki citra diri yang positif tentang kemampuan belajar mereka sendiri. Tetapi angka tinggi tersebut menurun drastis menjadi hanya $18 \%$ waktu mereka berusia 16 tahun. Konsekuensinya, 4 dari 5 remaja dan orang dewasa memulai pengalaman belajarnya yang baru dengan perasaan ketidaknyamanan. Dalam keberhasilan pembelajaran, perlu partisipasi siswa secara aktif agar siswa dapat membangun sendiri pengalaman belajarnya sehingga akan lebih mudah diingat oleh siswa. Sebagai penunjang keberhasilan belajar siswa, gurupun harus merencanakan strategi belajar agar siswa dapat mencapai hasil belajar yang diharapkan.

Pembelajaran adalah upaya menciptakan iklim dan pelayanan terhadap kemampuan, potensi, minat, bakat, dan kebutuhan siswa yang beragam agar terjadi interaksi optimal. Hudojo (2005: 71-77) mengungkapkan bahwa belajar matematika adalah belajar tentang konsep dan struktur yang terdapat dalam bahasan yang sedang terjadi serta menemukan hubunganhubungan antara konsep-konsep dan strukturstruktur tersebut. Dalam mempelajari matematika harus dilakukan secara bertahap dan berurutan serta berdasar terhadap pengalaman belajar yang lalu. Hal ini dikarenakan struktur dalam matematika bersifat hierarkis, dari konsep rendah kemudian berlanjut ke konsep tingkat tinggi. Dari penjelasan tersebut dapat disimpulkan bahwa belajar matematika tidak boleh terputus-putus, karena sifatnya yang hierarkis sehingga harus dilakukan secara kontinu agar proses pembelajaran matematika lancar dan konsep yang dipelajari oleh siswa tidak terputus.

Analisis dalam Kamus Besar Bahasa Indonesia (Kusrini, 2014: 197) adalah penyelidikan suatu peristiwa (karangan, perbuatan, dsb) untuk mengetahui keadaan yang sebenarnya (sebab-musabab, duduk perkaranya, dsb). Kesalahan adalah kekeliruan, kekhilafan sesuatu yang salah. Dalam proses pembelajaran 
matematika kesalahan sering terjadi ketika siswa menyelesaikan soal matematika tertentu. Demikian halnya seseorang bisa melakukan kesalahan dalam belajar akibat memorinya tidak mampu lagi memproduksi ulang pengetahuan yang telah disimpannya. Kesalahan dapat digunakan guru sebagai alat bantu melihat sejauh mana pemahaman siswa dalam proses belajar yang telah berlangsung sehingga akan diketahui kesulitan-kesulitan siswa.

Kesalahan menurut Kamus Besar Bahasa Indonesia (2007 : 982) berasal dari kata dasar "salah" yang artinya tidak benar, tidak betul atau keliru. Jadi, kesalahan dalam menyelesaikan soal matematika berarti siswa tidak benar dalam menyelesaikan soal matematika. Gagne (Andar dan Ikman, 2016: 17) telah membagi objek-objek matematika yang diperoleh siswa menjadi objek langsung dan objek tak langsung. Objek langsung terdiri dari fakta (fact), konsep (concept), prinsip (principle), dan keterampilan (skill). Sedangkan contoh objek tak langsungnya adalah berpikir logis, kemampuan memecahkan masalah, sikap positif terhadap matematika. Jadi objek tak langsung adalah kemampuan yang secara tak langsung akan dipelajari siswa ketika mereka mempelajari objek langsung matematika. Lebih lanjut E.G. Begle (Andar dan Ikman, 2016: 17), menyatakan bahwa objek matematika terbagi dalam empat jenis, yaitu: fakta, konsep, operasi, dan prinsip. Sedangkan Rika (2014: 25-26) dalam penelitiannya, jenis kesalahan siswa dalam menyelesaikan soal persamaan dan pertidaksamaan linear satu variabel terdiri atas 4 kesalahan, yakni 1) kesalahan konsep, 2) kesalahan prinsip, 3) kesalahan operasi, dan 4) kesalahan tidak menjawab soal yang telah diberikan.

Berdasarkan uraian tersebut, berkaitan dengan kesalahan siswa dalam mempelajari matematika, hubungannya dengan penelitian ini yaitu kesalahan yang dilakukan siswa dalam menyelesaikan soal-soal bentuk persamaan dan pertidaksamaan linear satu variabel yang ditinjau dari objek matematika yaitu fakta, konsep, prinsip, dan operasi.

\section{Metode}

Penelitian ini dilaksanakan pada semester ganjil tahun ajaran 2017/2018 pada siswa kelas VII SMP Negeri 2 Kendari yang terdiri atas 10 kelas paralel. Untuk keperluan penelitian ini, kelas yang menjadi subjek penelitian yaitu kelas VII.A yang terdiri atas 15 orang siswa laki-laki dan 13 orang siswa perempuan. Pengambilan kelas dalam penelitian ini dilakukan berdasarkan pertimbangan bahwa kelas VII.A adalah kelas yang mempunyai kemempuan matematika sedang jika dibandingkan dengan kelas-kelas VII yang lain. Dalam menentukan siswa yang terpilih sebagai subjek penelitian yang akan diwawancarai dalam penelitian ini digunakan teknik purposive sampling, yaitu penelitian yang menggunakan teknik penentuan subjek dengan kriteria tertentu (purposif).

Lincoln dan Guba (1985), dalam penelitian naturalistik, spesifikasi sampel tidak dapat ditentukan sebelumnya. Ciri-ciri khusus sampel purposif, yaitu 1) Emergent sampling design/sementara, 2) serial selection of sample unit/menggelinding seperti bola salju(snow ball), 3) continous adjustment ot 'focusing' of the sample/ disesuaikan dengan kebutuhan, 4) selectionto the point of redundancy/ dipilih sampai jenuh. Jadi, penentuan sampel dalam penelitian kualitatif dilakukan saat peneliti mulai memasuki lapangan dan selama penelitian berlangsung (emergent sampling design). Caranya yaitu, peneliti memilih orang tertentu yang dipertimbangkan akan memberikan data yang diperlukan; selanjutnya berdasarkan data atau informasi yang diperoleh dari sampel sebelumnya itu peneliti dapat menentukan sampel lainnya yang dipertimbangkan akan memberikan data lebih lengkap (Sugiyono, 20016: 301).

Penentuan siswa yang terpilih sebagai subyek yang akan diwawancarai dalam penelitian ini, akan dilakukan langkah-langkah berikut:

1. Memperhatikan siswa yang banyak membuat kesalahan dalam menjawab setiap butir soal.

2. Memperhatikan variasi kesalahan yang dilakukan siswa (fakta, konsep, prinsip, dan operasi).

Berdasarkan kriteria tersebut, maka siswa yang terpilih sebagai subjek penelitian yang akan diwawancara adalah berjumlah 3 orang siswa. Untuk lebih jelasnya dapat dilihat pada Tabel 1 berikut: 
Tabel 1.

Siswa yang terpilih sebagai subjek penelitian yang diwawancara

\begin{tabular}{|c|l|c|c|c|c|c|}
\hline \multirow{2}{*}{ No } & \multirow{2}{*}{ N a m a } & \multirow{2}{*}{ Kode } & \multicolumn{4}{|c|}{ Jenis Kesalahan yang Dilakukan } \\
\cline { 4 - 7 } & & & Fakta & Konsep & Prinsip & Operasi \\
\hline 1. & Wa Ode Nur Awaliya & S-27 & 0 & 3 & 4 & 3 \\
\hline 2. & Atika Madu Sari & S-07 & 1 & 3 & 2 & 2 \\
\hline 3. & Dwiramadan Saputra & S-11 & 0 & 1 & 3 & 2 \\
\hline
\end{tabular}

Variabel dalam penelitian ini adalah kesalahan siswa dalam menyelesaikan soal matematika materi pokok persamaan dan pertidaksamaan linear satu variabel yang meliputi hal-hal berikut:

1. Kesalahan fakta adalah kekeliruan dalam menuliskan konvensi-konvensi yang dinyatakan dengan simbol-simbol atau satuan dalam matematika.

2. Kesalahan konsep adalah kesalahan yang dilakukan siswa berkaitan dengan definisi konsep koefisien, variabel, dan konstanta, salah dalam menyamakan kedua ruas, dan salah dalam menerjemahkan soal cerita kedalam model matematika.

3. Kesalahan prinsip adalah kesalahan dalam menggunakan aturan-aturan atau rumusrumus matematika atau salah dalam menggunakan prinsip-prinsip yang berkaitan dengan materi, seperti salah dalam menyelesaikan jawaban dan salah dalam menentukan jawaban akhir soal dan dalam penarikan kesimpulan.

4. Kesalahan operasi adalah kesalahan dalam melakukan operasi atau perhitungan dimana siswa tidak dapat menggunakan aturan operasi atau perhitungan dengan benar.

Instrumen atau alat penelitian dalam penelitian kualitatif adalah peneliti itu sendiri. Segala sesuatu yang akan dicari dari obyek penelitian belum jelas dan pasti masalahnya, sumber datanya, hasil yang diharapkan semuanya belum jelas. Rancangan penelitian masih bersifat sementara dan akan berkembang setelah peneliti memasuki obyek penelitian. Dengan demikian dalam penelitian kualitatif ini belum dapat dikembangkan instrumen penelitian sebelum masalah yang diteliti jelas sama sekali. Oleh karena itu dalam penelitian kualitatif "the researcher is the key Instrumen". Jadi peneliti adalah merupakan instrumen kunci dalam penelitian kualitatif (Sugiyono, 2016: 306).
Teknik pengumpulan data dalam penelitian ini adalah dengan cara Observasi, pemberian tes, wawancara, dan triangulasi. Observasi dilakukan untuk mendapatkan informasi yang diperlukan untuk menyajikan gambaran riil suatu peristiwa atau kejadian untuk menjawab pertanyaan penelitian. Melalui observasi ini peneliti dapat mengetahui aktivitas yang dilakukan antara guru dan siswa saat proses pembelajaran berlangsung. Bentuk tes yang dilakukan dalam penelitian ini adalah bentuk tes tertulis yang berbentuk uraian. Tes disusun oleh peneliti dan dikonsultasikan ke dosen pembimbing. Butir soal pada tes dilakukan uji validitas yang dilakukan oleh pakar yang terdiri dari dosen pendidikan matematika UHO dan guru matematika SMP Negeri 2 Kendari. Tes bertujuan untuk mengetahui lebih awal tentang deskripsi kesalahan-kesalahan siswa dalam menyelesaikan soal-soal persamaan dan petidaksamaan linear satu variabel. Pemberian tes direncanakan akan dilakukan setelah penyajian materi persamaan dan pertidaksamaan linear satu variabel. Wawancara digunakan sebagai teknik pengumpulan data untuk mengetahui hal-hal dari responden yang lebih mendalam. Responden dimaksud adalah siswa dan guru. Wawancara dengan siswa dilakukan untuk mengetahui lebih lanjut kesalahan siswa dalam menyelesaikan soal-soal persamaan dan pertidaksamaan linear satu variabel. Sedangkan wawancara dengan guru dilakukan dengan tujuan untuk mengetahui penyebab kesalahan siswa dalam menyelesaikan soal-soal persamaan dan pertidaksamaan linear satu variabel.

Teknik pengumpulan data triangulasi diartikan sebagai teknik pengumpulan data yang bersifat menggabungkan dari berbagai teknik pengumpulan data dan sumber data yang telah ada (Sugiyono, 2014: 273 - 274), bila peneliti melakukan pengumpulan data dengan triangulasi, maka sebenarnya peneliti mengumpulkan data yang sekaligus menguji 
kredibilitas data, yaitu mengecek kredibilitas data dengan berbagai teknik pengumpulan data dan berbagai sumber. Terdapat 3 triangulasi dalam keabsahan data, yaitu triangulasi sumber, triangulasi teknik dan triangulasi waktu. Triangulasi dalam penelitian ini adalah triangulasi teknik, yaitu dengan membandingkan data hasil tes yang diverifikasi dengan wawancara, dan observasi.

Menurut Mudjiarahardjo (Sujarweni, 2014: 34), analisis data adalah sebuah kegiatan untuk mengatur, mengurutkan, mengelompokkan, memberi kode atau tanda, dan mengkategorikannya sehingga diperoleh suatu temuan berdasarkan focus atau masalah yang ingin dijawab. Data yang diperoleh dalam penelitian ini berupa data hasil tes, hasil wawancara dan hasil observasi. Setelah data terkumpul dilakukan reduksi data yang bertujuan untuk memfokuskan pada hal-hal yang akan diteliti yaitu menganalisis jawaban siswa yang telah dipilih sebagai subjek penelitian. Analisis data dalam penelitian ini dilakukan dengan langkah-langkah sebagai berikut.

1. Reduksi data yaitu kegiatan yang mengacu kepada proses mentrasformasikan data mentah yang tertulis di lapangan, menyeleksi, menyederhanakan dan mengelompokkan. Kegiatan ini dilakukan untuk menghindari penumpukan data atau informasi yang sama dari siswa. Tahap reduksi dalam penelitian ini meliputi: (a) melakukan observasi dan menyusun hasil observasi; (b) mengoreksi hasil pekerjaan siswa dan yang akan digunakan untuk menentukan subjek penelitian; dan (c) melakukan wawancara dengan beberapa subjek penelitian dan hasil wawancara tersebut disederhanakan menjadi susunan bahasa yang baik dan rapi.

2. Penyajian data adalah sekumpulan informasi tersusun yang memberi kemungkinan penarikan kesimpulan dan pengambilan tindakan. Dalam tahap ini data yang berupa hasil pekerjaan siswa disusun menurut urutan objek penelitian. Kegiatan ini memunculkan dan menunjukkan kumpulan data yang terorganisasi dan terkategori yang memungkinkan suatu penarikan kesimpulan atau tindakan. Data yang disajikan berupa jenis-jenis kesalahan siswa dalam menyelesaikan soal-soal persamaan dan pertidaksamaan linear satu variabel beserta penyebabnya. Penyajian data penelitian ini diantaranya: a) menyajikan data hasil observasi; b) menyajikan hasil pekerjaan siswa yang telah dipilih sebagai subjek penelitian; c) menyajikan data hasil wawancara yang berupa pekerjaan siswa dan hasil wawancara dilakukan analisis, kemudian disimpulkan hasil yang telah dilakukan sehingga dapat menjawab permasalahan dalam penelitian ini.

3. Penyimpulan dan Verifikasi merupakan langkah lebih lanjut dari kegiatan reduksi dan penyajian data. Hasil

\section{Data Hasil Tes}

Tes diberikan kepada siswa setelah seluruh materi selesai diberikan. Tes yang dilakukan merupakan tes diagnostik kesalahan. Berdasarkan hasil pekerjaan siswa dalam mengerjakan soal-soal pada materi persamaan dan pertidaksamaan linear satu variabel, ditemukan kesalahan-kesalahan yang dilakukan oleh siswa. Kesalahan-kesalahan tersebut disajikan sebagai berikut.

Tabel 2.

Deskripsi Kesalahan Jawaban Siswa pada Soal Nomor 1

\begin{tabular}{|l|c|}
\hline \multicolumn{1}{|c|}{ Deskripsi kesalahan Siswa } & \multicolumn{1}{c|}{ Nomor Subjek } \\
\hline $\begin{array}{l}\text { 1. Siswa keliru dalam mengoperasikan } \\
\text { penyelesaian soal. }\end{array}$ & $02,07,10,16,18,19,22,23$, dan 27 \\
\hline $\begin{array}{l}\text { 2. Siswa salah dalam menyelesaikan atau } \\
\text { menentukan jawaban. }\end{array}$ & $09,10,16,19,23$, dan 27 \\
\hline 3. Siswa salah dalam menyamakan kedua ruas. & $01,03,07,12$, dan 22 \\
\hline
\end{tabular}


Berdasarkan Tabel 2 diatas, kesalahankesalahan yang dilakukan siswa pada soal nomor 1 meliputi: (1) Kesalahan fakta. Tidak ada siswa yang melakukan kesalahan fakta dalam menjawab soal nomor 1; (2) Kesalahan konsep. Siswa yang melakukan kesalahan konsep dalam menjawab butir soal 1 sebanyak 5 orang.. Siswa yang melakukan kesalahan tersebut yaitu siswa dengan nomor responden
01, 03, 07, 12, dan 22; (3) Kesalahan prinsip. Siswa yang melakukan kesalahan tersebut yaitu siswa dengan nomor responden 09, 10, 16, 19, 23, dan 27; dan (4) Kesalahan operasi. Siswa yang melakukan kesalahan operasi dalam menjawab butir soal 1 sebanyak 9 orang. yaitu siswa dengan nomor responden $02,07,10,16$, 18, 19, 22, 23, dan 27.

Tabel 3.

Deskripsi Kesalahan Jawaban Siswa pada Soal Nomor 2

\begin{tabular}{|ll|l|}
\hline \multicolumn{2}{|c|}{ Deskripsi kesalahan siswa } & \multicolumn{1}{c|}{ Nomor Subjek } \\
\hline 1. & $\begin{array}{l}\text { Siswa tidak dapat menerjemahkan soal cerita } \\
\text { kedalam model matematika. }\end{array}$ & $\begin{array}{l}\text { Semua siswa kecuali 02, 05, 09, 14, } \\
\text { dan 20 }\end{array}$ \\
\hline 2. & Siswa salah dalam menyelesaikan jawaban. & $02,03,05,11,14,20,27$ \\
\hline 3. & Siswa tidak menjawab soal & 09 \\
\hline
\end{tabular}

Berdasarkan Tabel 3 diatas, kesalahankesalahan yang dilakukan sisw pada soal nomor 1 meliputi: (1) Kesalahan Fakta. Tidak ada siswa yang melakukan kesalahan fakta pada butir soal nomor 2; (2) Kesalahan konsep. Siswa yang melakukan kesalahan konsep pada butir soal 2 sebanyak 23 orang. Siswa yang melakukan kesalahan tersebut adalah semua siswa kecuali siswa dengan nomor responden 02, 05, 09, 14, dan 20; (3) Kesalahan Prinsip. Siswa yang melakukan kesalahan prinsip dalam menjawab soal nomor 2 sebanyak 7 orang. Siswa yang melakukan kesalahan tersebut yaitu siswa dengan nomor responden 02, 03, 05, 11, 14, 20, dan 27; dan (4) Kesalahan operasi. Tidak ada siswa yang melakukan kesalahan operasi.

Tabel 4.

Deskripsi Kesalahan Jawaban Siswa pada Soal Nomor 3

\begin{tabular}{|ll|l|}
\hline \multicolumn{2}{|c|}{ Deskripsi kesalahan siswa } & \multicolumn{1}{c|}{ Nomor Subjek } \\
\hline 1. & Siswa salah dalam menyamakan kedua ruas. & $\begin{array}{l}02,03,09,10,12,13,16,18,19,21, \\
22,23,24,26,27, \text { dan 28 }\end{array}$ \\
\hline 2. & $\begin{array}{l}\text { Siswa keliru dalam mengoperasikan } \\
\text { penyelesaian soal. }\end{array}$ & $\begin{array}{l}03,04,06,07,10,11,13,15,19,25, \\
\text { dan 27. }\end{array}$ \\
\hline 3. & Siswa salah dalam menyelesaikan jawaban. & $04,05,07,08,11,14,15,17$, dan 27 \\
\hline 4. & Siswa tidak menjawab soal. & 01 \\
\hline
\end{tabular}

Berdasarkan Tabel 4 diatas, kesalahankesalahan yang dilakukan sisw pada soal nomor 1 meliputi: (1) Kesalahan Fakta. Tidak ada siswa yang melakukan kesalahan fakta; (2) Kesalahan konsep. Siswa yang melakukan kesalahan konsep dalam menjawab butir soal 3 adalah sebanyak 16 orang.. Siswa yang melakukan kesalahan tersebut adalah siswa dengan nomor responden 02, 03, 09, 10, 12, 13, $16,18,19,21,22,23,24,26,27$, dan 28; (3)
Kesalahan prinsip. Siswa yang melakukan kesalahan prinsip dalam menjawab butir soal 3 adalah sebanyak 9 orang yaitu siswa dengan nomor responden 04, 05, 07, 08, 11, 14, 15, 17, dan 27; dan (4) Kesalahan operasi. Siswa yang melakukan kesalahan operasi dalam menjawab butir soal 3 sebanyak 11 orang yaitu siswa dengan nomor responden 03, 04, 06, 07, 10, 11, 13, 15, 19, 25, dan 27. 
Tabel 5.

Deskripsi Kesalahan Jawaban Siswa pada Soal Nomor 4

\begin{tabular}{|ll|l|}
\hline \multicolumn{2}{|c|}{ Deskripsi kesalahan siswa } & \multicolumn{1}{c|}{ Nomor Subjek } \\
\hline 1. & Siswa salah dalam menyamakan kedua ruas & $\begin{array}{l}03,04,06,07,12,18,19,21,22,23, \\
24,26, \text { dan } 28\end{array}$ \\
\hline 2. & Siswa keliru dalam mengoperasikan soal. & $05,08,10,11,14,15,17$, dan 27 \\
\hline 3. & Siswa salah dalam menyelesaikan soal & $02,10,13,17,20.22$, dan 27 \\
\hline 4. & Siswa tidak menjawab soal & 01,16, dan 25 \\
\hline
\end{tabular}

Berdasarkan Tabel 5 diatas, kesalahankesalahan yang dilakukan sisw pada soal nomor 1 meliputi: (1) Kesalahan Fakta. Tidak ada siswa yang melakukan kesalahan Fakta; (2) Kesalahan konsep. Siswa yang melakukan kesalahan konsep dalam menjawab butir soal 4 sebanyak 13 orang yaitu siswa dengan nomor responden 03, 04, 06, 07, 12, 18, 19, 21, 22, 23, 24, 26, dan 28; (3) Kesalahan prinsip. Siswa yang melakukan kesalahan prinsip dalam menyelesaikan butir soal nomor 4 adalah sebanyak 7 orang. yaitu siswa dengan nomor responden $02,10,13,17,20.22$, dan 27 ; dan (4) Kesalahan operasi. Siswa yang melakukan kesalahan operasi adalah sebanyak 8 orang. yaitu siswa dengan nomor responden $05,08,10$, 11, 14, 15, 17, dan 27.

Tabel 6.

Deskripsi Kesalahan Jawaban Siswa pada Soal Nomor 5

\begin{tabular}{|c|c|}
\hline Deskripsi kesalahan siswa & Nomor Subjek \\
\hline $\begin{array}{l}\text { 1. Siswa tidak dapat menerjemahkan soal cerita } \\
\text { kedalam model matematika. }\end{array}$ & $\begin{array}{l}02,03,04,06,09,10,13,16,18,19, \\
21,22,23,24,26,27 \text {, dan } 28\end{array}$ \\
\hline $\begin{array}{l}\text { 2. Siswa keliru dalam menentukan penyelesaian } \\
\text { soal. }\end{array}$ & $05,07,08,11,14,15,17$, dan 20 \\
\hline 3. Siswa keliru dalam menuliskan satuan. & $05,07,08,11,14,15,17$, dan 20. \\
\hline 4. Siswa tidak menjawab soal & 01,12 , dan 25 \\
\hline
\end{tabular}

Berdasarkan Tabel 6 diatas, kesalahankesalahan yang dilakukan sisw pada soal nomor 1 meliputi: (1) Kesalahan Fakta. Siswa yang melakukan kesalahan Fakta dalam menyelesaikan butir soal 5 adalah sebanyak 8 orang yaitu siswa dengan nomor responden 05 , 07, 08, 11, 14, 15, 17, dan 20; (2) Kesalahan Konsep. Siswa yang melakukan kesalahan konsep dalam menjawab butir soal 5 adalah sebanyak 17 orang yaitu siswa dengan nomor responden $02,03,04,06,09,10,13,16,18,19$, 21, 22, 23, 24, 26, 27, dan 28; (3) Kesalahan prinsip. Siswa yang melakukan kesalahan prinsip dalam menjawab butir soal nomor 5 sebanyak 8 orang yaitu siswa dengan nomor responden 05, 07, 08, 11, 14, 15, 17, dan 20; dan (4) Kesalahan operasi. Tidak ada siswa yang melakukan kesalahan operasi dalam menyelesaikan butir soal nomor 5 .

\section{Hasil Analisis Data}

Berdasarkan kesalahan-kesalahan yang dilakukan siswa, untuk mengetahui penyebab terjadinya kesalahan dan memastikan kesalahan tersebut, dipilih beberapa siswa untuk dianalisis jawabannya. Pada deskripsi kesalahan yang dilakukan siswa dalam menyelesaikan soal di atas, siswa dikelompokkan berdasarkan jenis kesalahan yang dilakukan ditinjau dari kesalahan fakta, kesalahan konsep, kesalahan prinsip, dan kesalahan operasi. Berikut ini disajikan hasil tes 3 orang siswa yang telah menjadi subjek (S) penelitian dari penelitian ini.

a) Analisis Kesalahan Jawaban Siswa Nomor Subjek 07

Soal nomor 1 


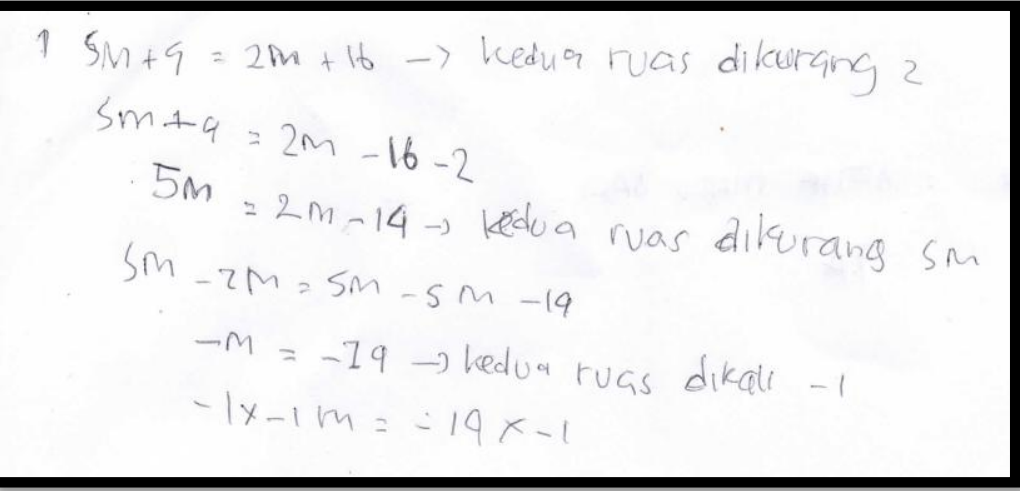

Gambar 1. Jawaban nomor 1 siswa S-07

Dari gambar 1 terlihat siswa S-07 tidak dapat menyamakan kedua ruas dengan benar sehingga langkah dalam menyelesaikan jawaban

Soal nomor 2 salah. Jenis kesalahan ini dikategorikan sebagai kesalahan konsep.

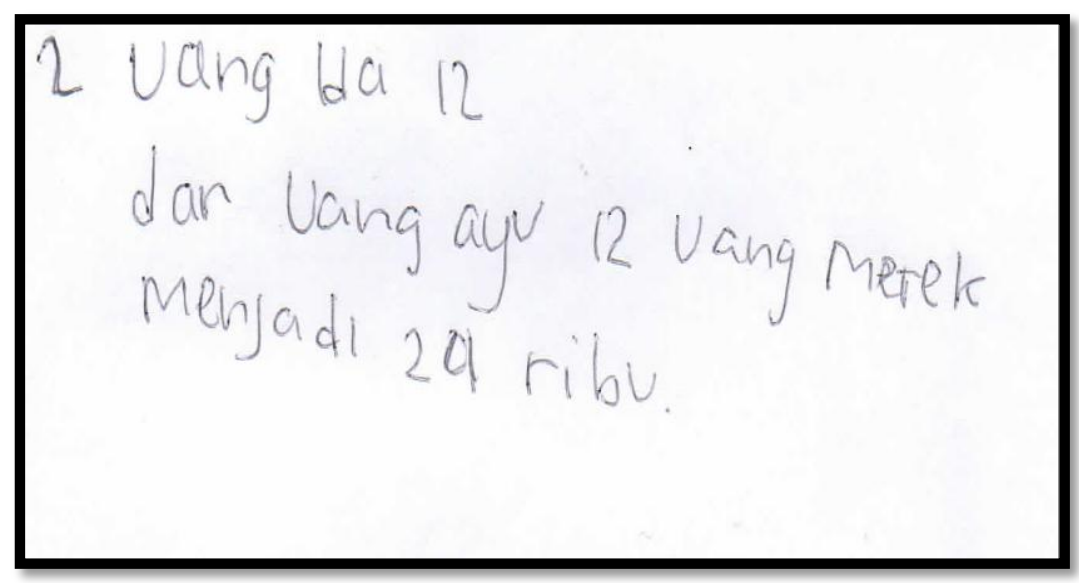

Gambar 2. Jawaban nomor 2 siswa S-07

Dari gambar 2 terlihat siswa S-07 salah dalam menjawab soal. Siswa tidak mengerti cara memodelkan bentuk soal cerita kedalam model matematika sehingga siswa hanya memnulis jawaban akhir dari temannya. Jenis kesalahan tersebut dapat dikategorikan sebagai kesalahan konsep.

b. Analisis Kesalahan Jawaban Siswa Nomor Subjek 11

Soal nomor 3 


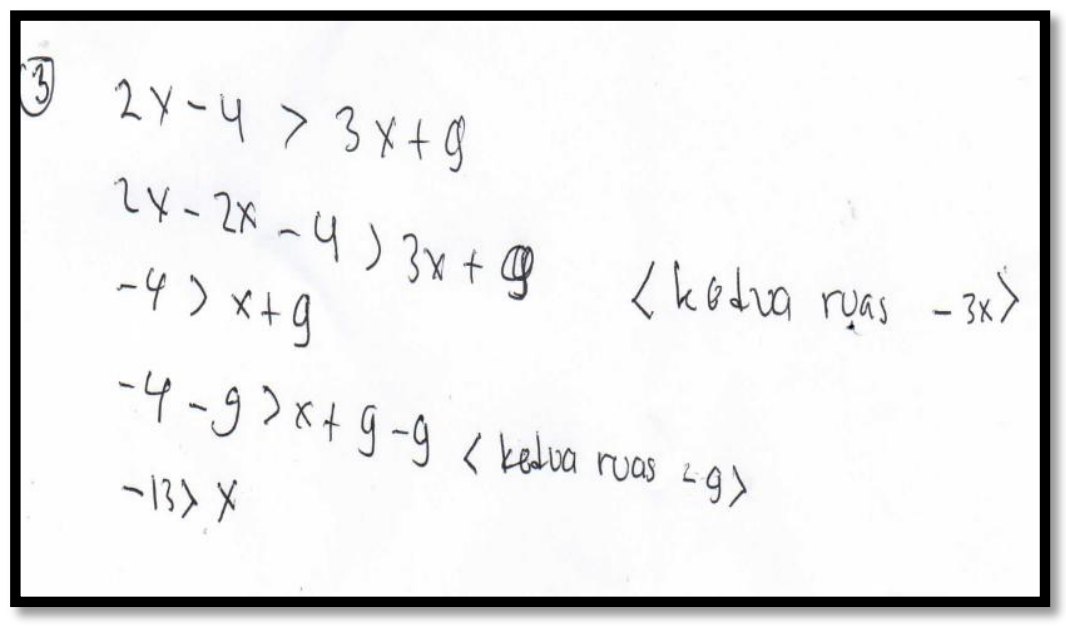

Gambar 3. Jawaban nomor 3 siswa S-11

Dari gambar 3 terlihat siswa S-11 salah dalam menyelesaikan soal. Siswa salah dalam melakukan operasi atau perhitungan dengan benar. Jenis kesalahan tersebut dikategorikan sebagai kesalahan operasi.

Soal nomor 5

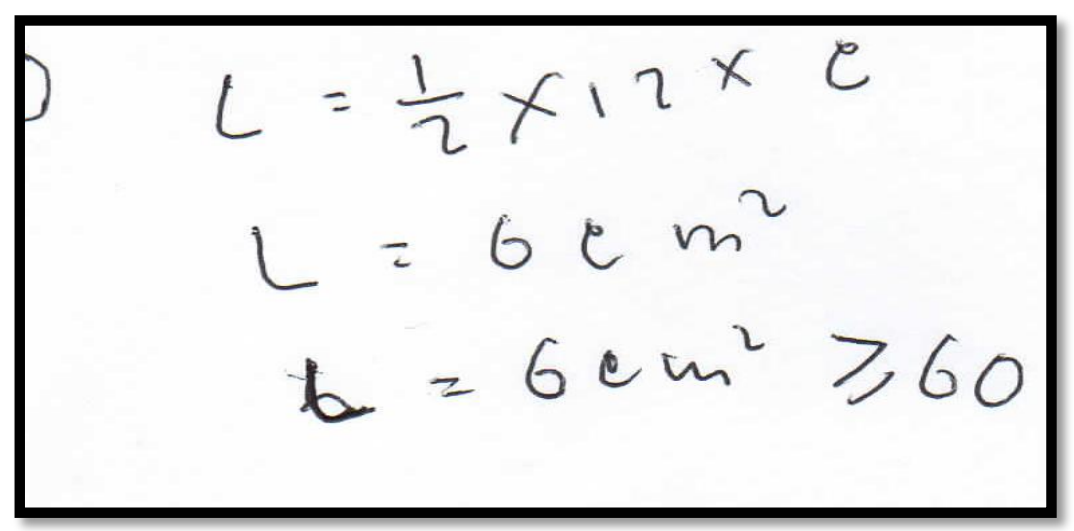

Gambar 4. Jawaban nomor 5 siswa S-11

Dari gambar 4 terlihat siswa S-11 tidak memahami apa yang harus dilakukan selanjutnya setelah menuliskan rumus yang digunakan. Siswa tidak dapat mengaitkan rumus yang digunakan tersebut dengan luas minimal kebun yang diketahui sehingga siswa langsung menulis jawaban akhir dari temannya tanpa menyelesaikan langkah yang seharusnya. Jenis kesalahan tersebut dikategorikan sebagai kesalahan prinsip.

c. Analisis Kesalahan Jawaban Siswa Nomor Subjek 27

Soal Nomor 2 


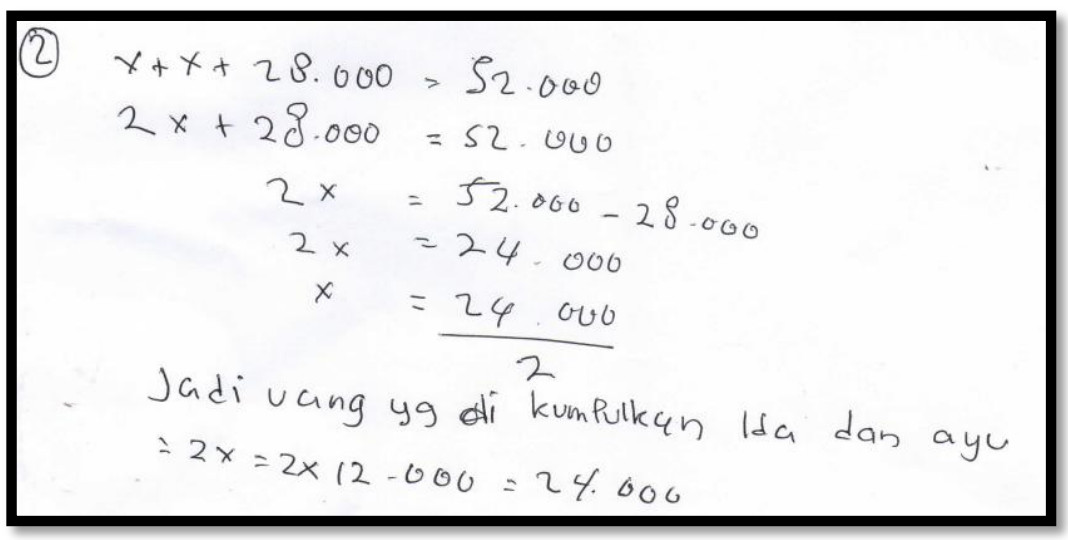

Gambar 5. Jawaban nomor 2 siswa S-27

Dari gambar 5 terlihat siswa S-27 keliru dalam memahami soal. Siswa tersebut memisalkan Ida dan Ayu dengan simbol yang sama sehingga persamaan yang digunakan untuk menentukan jumlah uang Ida dan Ayu salah. siswa keliru dalam memahami soal dengan baik. Pertanyaan yang seharusnya adalah menentukan persamaan yang digunakan untuk menentukan jumlah uang Ida dan Ayu, sementara S-27 hanya menentukan jumlah uang keduanya. Karena siswa tersebut salah dalam menyelesaikan soal, maka kesalahan siswa dikategorikan sebagai kesalahan prinsip.

Soal nomor 4

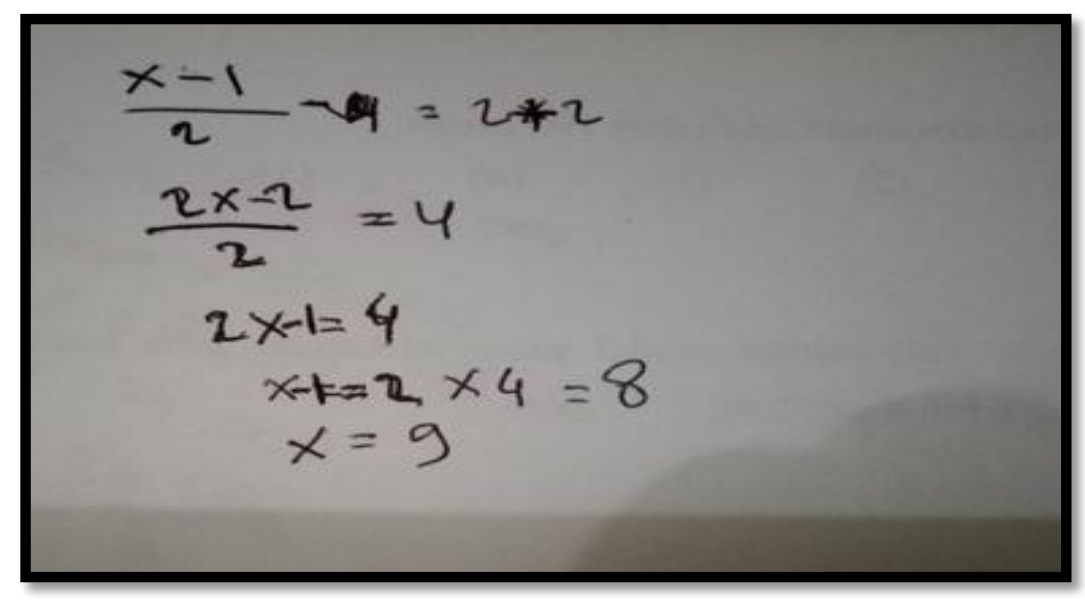

Gambar 6. Jawaban nomor 4 siswa S-27

Dari gambar 6 terlihat siswa S-27 melakukan kesalahan dalam menyelesaikan soal. Jawaban akhir siswa sebenarnya sudah benar, tetapi siswa tidak memperhatikan langkah penyelesaiannya dengan seksama. Pertama siswa menambahkan bilangan 2 dikedua ruas, selanjutnya siswa mengalikan bilangan 2 dikedua ruas tetapi diruas kanan siswa tidak mengalikan dengan bilangan 2. Selain itu, siswa juga salah dalam perhitungan $\frac{2 x-2}{2}$ dikalikan dengan 2. Siswa tidak mengalikan bilangan 4 dengan bilangan 2 . Kesalahan siswa tersebut dikategorikan sebagai kesalahan operasi. d. Analisis Hasil Wawancara dengan Guru Berdasarkan hasil wawancara dengan guru diperoleh sebagai berikut:

1. Siswa kurang aktif dalam mengikuti proses pembelajaran. Hanya beberapa siswa yang aktif dalam menjawab pertanyaan atau menjawab soal di depan kelas ketika mempelajari materi persamaan dan pertidaksamaan linear satu variabel.

2. Saat guru menjelaskan, perhatian siswa berada ditempat lain. Hanya beberapa siswa saja yang memperhatikan penjelasan guru dengan baik. 
3. Pokok bahasan yang sulit dipahami siswa pada materi persamaan dan pertidaksamaan linear satu variabel yaitu menyamakan kedua ruas dan menyelesaikan soal yang berbentuk soal cerita.

4. Kesulitan siswa dalam mempelajari materi persamaan dan pertidaksamaan linear satu variabel disebabkan karena kurangnya pengetahuan dasar siswa atau pengetahuan mengenai materi parasyarat persamaan dan pertidaksamaan linear satu variabel. Namun, guru tidak dapat menjelaskan mengenai materi-materi dasar atau materi prasyarat yang kurang dikuasai siswa secara lebih jauh karena keterbatasan waktu.

5. Metode mengajar yang diterapkan oleh guru adalah pembelajaran langsung. Mengantar pemahaman siswa melalui metode ceramah dan pemberian contoh sambil mengingatkan kembali konsepkonsep dasar yang berhubungan, kemudian memberikan beberapa soal untuk mereka kerjakan di papan tulis. Mengarahkan siswa untuk saling kerja sama dan berdiskusi saat mengerjakan soal, dan memberi kesempatan jika ada siswa yang bertanya kepada guru saat diskusi berlangsung.

6. Cara guru mengatasi kesulitan siswa dalam mempelajari persamaan dan pertidaksamaan linear satu variabel yaitu mengulangi beberapa penjelasan pada bagian yang belum dipahami. Kemudian guru memberikan soal kepada siswa dengan model yang sama lalu disuruh untuk dikerjakan dan dipresentasekan di papan tulis.

7. Motivasi siswa dalam mempelajari matematika khususnya materi persamaan dan pertidaksamaan linear satu variabel masih kurang. Hal ini terlihat dari siswa yang jarang mempelajari matematika di rumah. Siswa hanya membuka buku catatan atau buku paket hanya ketika pelajaran matematika berlangsung di kelas.

8. Dari 3 siswa yang dijadikan subjek wawancara, semua siswa dianggap masih sangat kurang dalam menguasai materi persamaan dan pertidaksamaan linear satu variabel.

\section{Pembahasan}

Berdasarkan hasil penelitian di atas, kesalahan yang dilakukan oleh siswa dalam menyelesaikan soal persamaan dan pertidaksamaan linear satu variabel adalah kesalahan fakta, kesalahan konsep, kesalahan prinsip, dan kesalahan operasi. Dari keempat jenis kesalahan tersebut, yang paling banyak dilakukan oleh siswa untuk keseluruhan butir soal adalah kesalahan konsep. Dari hasil analisis data yang meliputi reduksi data, penyajian data, dan verifikasi atau pengecekan data diperoleh jenis-jenis kesalahan yang dilakukan siswa dalam menyelesaikan soal-soal pada materi persamaan dan pertidaksamaan linear satu variabel adalah sebagai berikut.

Kesalahan fakta terjadi pada siswa yang melakukan kesalahan menuliskan satuan dalam penyelesaian soal. Hal ini disebabkan siswa kurang teliti dalam menyelesaikan soal dan tidak memperhatikan kembali jawaban yang sudah dikerjakan. Kesalahan fakta hanya dilakukan siswa pada butir soal 5 yakni sebanyak 8 orang.

Kesalahan konsep yang dilakukan siswa dalam penelitian ini adalah salah dalam menggunakan konsep persamaan dan pertidaksamaan linear satu variabel yaitu siswa salah dalam menyamakan kedua ruas dan salah dalam mengubah soal cerita kedalam kalimat matematika. Pada butir soal nomor 1, nomor 3, dan nomor 4 beberapa siswa tidak dapat menyelesaikannya dikarenakan siswa tidak memahami konsep dengan baik sebagaimana ditunjukkan pada analisis data diatas oleh siswa S-07. Siswa salah dalam menyamakan kedua ruas. Berdasarkan hasil wawancara, siswa kebingungan dan masih belum mengerti terkait cara dalam menyamakan kedua ruas. Pada soal nomor 2, Siswa menyelesaikan soal hanya dengan menjawab langsung pada kesimpulan. Sebagaimana ditunjukkan pada analisis data diatas oleh siswa S-07. Berdasarkan hasil wawancara siswa mengatakan tidak mengerti dalam menyelesaikan soal cerita sehingga siswa tersebut meminta simpulan jawaban dari temannya. Pada soal nomor 5, semua siswa tidak dapat menyelesaikannya, banyak siswa yang tidak memahami maksud dari soal tersebut sehingga siswa hanya memberikan simpulan jawaban tanpa menyelesaikan. Sama halnya dengan nomor 2, siswa masih belum paham 
dalam menyelesaikan soal dalam bentuk soal cerita.

Kesalahan prinsip yang dilakukan siswa terkait persamaan dan pertidaksamaan linear satu variabel paling banyak terjadi pada butir soal nomor 5. Pada soal nomor 5 kebanyakan siswa keliru dalam menyelesaikan soal. Sebagaimana hasil analisis data diatas oleh S-11, berdasarkan hasil wawancara S-11, siswa mengaku bahwa masih bingung dalam menyelesaikan soal. Hal ini dikarenakan siswa masih kurang paham dalam menerjemahkan soal cerita sehingga siswa salah dalam menyelesaikan soal. Sama halnya dengan butir soal nomor 2, siswa masih kurang dalam menerjemahkan soal maupun memahami soal dengan baik. Pada soal nomor 1, 3 dan nomor 4, siswa tidak dapat menyelesaikan jawaban soal dengan benar dan siswa salah dalam menetukan jawaban akhir soal atau tidak dapat menyimpulkan dengan benar.

Kesalahan operasi disebabkan karena siswa kurang teliti dan tidak konsentrasi dalam menyelesaikan soal. Siswa paling banyak melakukan kesalahan operasi pada butir soal nomor 3. Sebagaimana hasil analisis diatas oleh S-11 berdasarkan hasil wawancara siswa keliru dalam mengoperasikan bilangan.

Berdasarkan analisis hasil tes, wawancara siswa, dan wawancara dengan guru maka ditemukan bahwa bagian yang sulit dipahami oleh siswa dalam mempelajari persamaan dan pertidaksamaan linear satu variabel adalah memahami konsep persamaan dan pertidaksamaan yakni menyamakan kedua ruas ataupun soal yang disajikan dalam bentuk cerita sehingga siswa sulit dalam menerjemahkannya. Siswa juga masih keliru dalam operasi perhitungan yang disebabkan kurangnya pengetahuan dan pemahaman siswa mengenai materi dasar yang merupakan materi prasyarat dari persamaan dan pertidaksamaan linear satu variabel. Selain itu, penyebab kesalahan yang dilakukan oleh siswa juga berhubungan dengan anggapan mereka yang sulit dalam mempelajari matematika. Angapan ini pula yang mempengaruhi motivasi dan aktivitas belajar siswa. Sehingga siswa tidak memiliki dorongan untuk belajar matematika dan cenderung tidak tertarik dengan pelajaran matematika.

\section{Simpulan dan Saran}

\section{Simpulan}

Berdasarkan hasil penelitian dan pembahasan maka dapat diambil kesimpulan sebagai berikut.

1. Kesalahan-kesalahan yang dilakukan siswa dalam menyelesaikan soal persamaan dan pertidaksamaan linear satu variabel adalah sebagai berikut.

a. Kesalahan fakta yaitu kesalahan atau kekeliruan siswa dalam menuliskan simbol dalam menjawab soal dan keliru dalam menuliskan bilangan terkait dengan soal yang diberikan.

b. Kesalahan konsep yaitu siswa tidak memahami penyamaan kedua ruas, dan siswa salah dalam menerjemahkan soal cerita kedalam model matematika.

c. Kesalahan prinsip yaitu kesalahan dalam menyelesaikan jawaban dan kesalahan dalam menentukan jawaban akhir serta penarikan kesimpulan.

d. Kesalahan operasi yaitu siswa tidak dapat menggunakan aturan operasi atau perhitungan dengan benar.

e. Kasus khusus yaitu siswa tidak menjawab soal.

2. Faktor penyebab sehingga siswa melakukan kesalahan dalam menyelesaikan soal persamaan dan pertidaksamaan linear satu variabel adalah sebagai berikut.

a. Siswa krrang teliti dalam membaca soal

b. Siswa tidak paham maksud dari soal yang diberikan sehingga tidak tahu bagaimana cara menjawab soal tersebut.

c. Siswa masih kurang paham bagaimana cara menyamakan kedua ruas

d. Siswa tidak tahu bagaimana cara mengubah soal menjadi model matematika pada soal cerita.

\section{Saran}

Berdasarkan kesimpulan di atas, penulis menawarkan beberapa saran untuk mengatasi kesalahan-kesalahan yang dilakukan siswa dalam menyelesaikan soal-soal tentang persamaan dan pertidaksamaan linear satu variabel yaitu:

1. Siswa lebih sering diingatkan untuk belajar bermakna agar materi dan konsep pelajaran 
yang diberikan akan membekas diingatan siswa (tidak hilang diigatan siswa) yaitu belajar matematika dengan cara memahami konsep dasar yang diberikan dengan pokok bahasan persamaan dan pertidaksamaan linear satu variabel.

2. Dalam proses belajar mengajar sebaiknya guru terlebih dahulu memberi materi prasyarat sebelum menjelaskan materi inti yang diajarkan.

3. Untuk siswa, sebaiknya lebih banyak belajar dan berlatih terutama mengenai materi-materi dasar atau materi prasyarat di rumah atau diluar jam pelajaran matematika agar mempermudah pemahaman siswa dalam mempelajari materi persamaan dan pertidaksamaan linear satu variabel

4. Untuk menghindari kesalahan akibat ketidak telitian yang juga banyak dilakukan siswa, maka dalam menyelesaikan soal aktivitas memeriksa kembali atau koreksi diperlukan. Untuk itu, dalam proses pembelajaran, siswa perlu dibiasakan untuk memeriksa kembali jawaban dari pekerjaan mereka.

\section{Daftar Pustaka}

Andar \& Ikman. (2016). Deskripsi Kesalahan Siswa dalam Menyelesaikan Soal-Soal Ujian Semester Matematika Siswa Kelas VIII SMP Negeri 10 Kendari. Jurnal Penelitian Pendidikan Matematika Volume 4 No. 2, hal. 1528.

Aunnurrahman. (2012). Belajar dan Pembelajaran. Bandung: Alfabeta.

BSNP. (2006). Standar Isi untuk Satuan Pendidikan Dasar dan Menengah. Jakarta:BSNP.

Depdiknas. (2007). Kamus Besar Bahasa Indonesia. Depdiknas. Jakarta.

Hudojo. (2005). Pengembangan Kurikulum dan Pembelajaran Matematika. Jakarta: Universitas Negeri Malang.

Kusrini. (2014). Analisis Kesalahan Siswa Kelas VIII Dalam Menyelesaikan Soal Pada Materi Faktorisasi Bentuk Aljabar SMP Negeri 1 Kamal Semester Gasal
Tahun Ajaran 2013/2014. Jurnal Ilmiah Pendidikan Matematika MATHEDUNESA Vol.3, No.2, Hal 195-205.

Meylan. (2013). Analisis Kesalahan Siswa dalam Menyelesaikan Soal-Soal pada Materi Garis Singgung Lingkaran. Skripsi. FMIPA. Universitas Negeri Gorontalo. Tersedi a: http://kim.ung.ac.id/index.php/KIM FMIPA/article/view/3363/3339. diakses 24 Januari 2017.

Muri yusuf, A. (2015). Esensi dan evaluasi pendidikan. Jakarta: Prenadamedia Group.

Rika, Febrianti. (2014). Identifikasi Kesalahan Siswa Kelas VII SMP Muhammadiyah Terpadu Kota Bengkulu dalam Menyelesaikan Soal-Soal Persamaan dan Pertidaksamaan Linear Satu Variabel. Skripsi Pendidikan Matematika Universitas Bengkulu.

Sugiyono, (2016). Metode Penelitian Pendidikan Pendekatan Kuantitatif, Kualitatif, dan $R \& D$. Bandung: Alfabeta.

Sujarweni. (2014). Metodologi Penelitian. Yogyakarta: Pustakabarupress. 